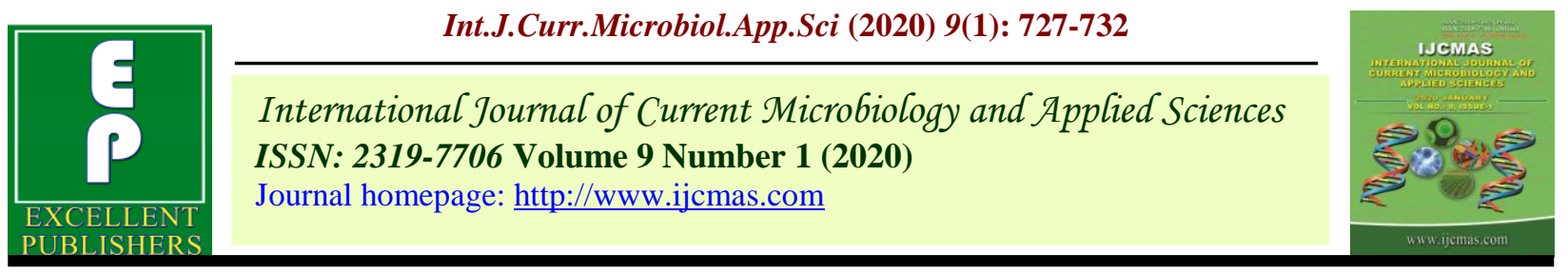

Original Research Article

https://doi.org/10.20546/ijcmas.2020.901.079

\title{
Effect of Bio fertilizers with Different Levels of N, P and K on physico-chemical Properties of Strawberry (Fragaria $x$ ananassa Duch.) $c v$. Chandler
}

\author{
Naiem Ansari, Sevan Das Khunte* and V.M. Prasad
}

Department of Horticulture, Allahabad School of Agriculture, Sam Higginbottom Institute of Agriculture, Technology and Sciences (Deemed to-be University), Allahabad - 211007 (Uttar Pradesh), India

*Corresponding author

\section{A B S T R A C T}

Keywords

Azotobacter, NPK, PSB and Strawberry

Article Info

Accepted:

15 December 2019

Available Online:

20 January 2020
A field experiment was carried out during the winter season at Crop Research Farm, Department of Horticulture, SHIATS, Allahabad, (U.P.) India. The maximum number of leaves per plant (20.56) was recorded with treatment $\mathrm{T}_{9}$ (5.50 tones poultry manure ${ }^{\text {ha- }}+\mathrm{GA}_{3} 150 \mathrm{ppm}^{1-1}$ the maximum fruit weight (g / fruit), maximum fruit index (Ratio of fruit length and fruit diameter), the maximum specific gravity of fruits, the maximum total soluble solid (T.S.S. ${ }^{0}$ Brix) of fruits, the maximum $\mathrm{pH}$ of fruit juice, the minimum acidity $(\%)$ of fruit juice, the maximum Vitamin $-\mathrm{C}$ content of fruits $(\mathrm{mg} / 100 \mathrm{~g})$ and the maximum juice content $(\%)$ of fruits was recorded in $\mathrm{T}_{9}$ : RDF 100\% (150:75:100 kg ha $\left.{ }^{-1}\right)+$ Azotobacter $6 \mathrm{~kg} \mathrm{ha}^{-1}+$ PSB $5 \mathrm{~kg} \mathrm{ha}^{-1}$ with $(23.18 \mathrm{~g})$. The minimum fruit weight $(\mathrm{g}$ / fruit) $(10.87 \mathrm{~g})$, minimum fruit index $(1.28$, minimum specific gravity of fruits(1.62), minimum total soluble solid (T.S.S. ${ }^{0}$ Brix) of fruits $(8.38)$, minimum $\mathrm{pH}$ of fruit juice (2.59), minimum acidity $(\%)$ of fruit juice $(0.71)$, minimum Vitamin $-\mathrm{C}$ content of fruits (mg / 100g) (47.13), minimum juice content (\%) of fruits $(80.42 \%)$ was recorded in $\mathrm{T}_{0}$ (control).

\section{Introduction}

Strawberry (Fragaria $x$ ananassa) is an aggregate fruit, which develops by simultaneous ripening of the number of separate berries of a single flower, adhering as common unit on the common receptacle, botanically called as "etaerio of achenes".
Strawberry is usually propagated through runners. Now a day, large scale propagation by tissue culture has been used widely in strawberry industry. Strawberry is well known as temperate fruit and growing commercially in many countries Israel, Japan, Turkey, Australia, and New Zealand. Poland produces strawberries only for processing 
(Mitra, 1991). In 2012, approximately $(1,292,780 \mathrm{MT}) 29.6 \%$ of the total production came from the United States of America, the other major strawberry producing countries are Turkey $(299,940 \mathrm{MT}) 6.8 \%$, Spain (275,300MT) 6.3\%, Egypt (238,432 MT) $5.4 \%$, Republic of Korea (231,803 MT) $5.3 \%$, Mexico and Poland (FAOSTAT 2013). In India it is found to be popular among the tourist on hill station like Ooctacamund, Shimla, Mahabalehwar on account of the attractive appearance, spritely flavour pleasant aroma and health giving properties. In India commercially and widely cultivated in Himachal Pradesh, Uttrakhand, Maharashtra, West Bengal, Nilgiri hills, Delhi, Haryana, Jammu and Kashmir Punjab and Rajasthan (Baba, 2010)

Strawberry can be grown in wide climatic conditions, ranging from temperate to tropical climate. Since its cultivation is greatly influenced by specific regional adaptation due to photoperiodic and temperature requirement, its cultural practices are highly variable. Among the different climatic factors, temperature and day length affect considerably the growth and yield of strawberry. Its flowering is strongly influenced by photoperiod, temperature and its interactions.

Growth and development of strawberry is highly sensitive to variations in air and soil temperature. An optimum growing season temperature of $15^{\circ} \mathrm{C}$ has been reported for most of the strawberry cultivars and species (Roberts and Kenworthy, 1956) have found range between 20 and $26^{\circ} \mathrm{C}$, the ambient temperature for proper growth. Plants grow very fast in plains and its starts bearing within three months of planting and in hills; it takes 9-12 months to come to bearing. However, the fruit quality is very good in hills as compared to plains. Similarly, the colour and flavor development is not proper in plains. Its plant is cherished in gardens in commercial field for its beautiful, red fruit that has a tantalizing aroma (Sharma and Yamdagni, 2000). The fresh ripe fruit of strawberry are the rich source of vitamins and minerals. Among vitamins, it is a fairly good source of vitamin A (60 I.U./100 g of edible portion) and vitamin C (30-120mg/100g of edible portion). It also has high pectin $(0.55 \%)$, available on the form of calcium pectate, which serves as an excellent ingredient for jelly making (Mitra, 1991). Besides, it also has abundance of minerals, like potassium, calcium and phosphorus. The T.S.S. contents of fruits comprise sugar, acids and other substances dissolved in cell sap. The mature soft fruit contains about $5 \%$ total sugar and $0.90 \%$ to $1.85 \%$ acids. Fructose and glucose are the major sugars found in strawberry with small proportion of sucrose (Forney and Breen, 1986). High yield and better quality fruits cannot be expected from the sole application of organic manures or biological products. Therefore, a judicious combination of inorganic and organic fertilizers or biofertilizers may be helpful in increasing the fruit production in strawberry (Shiowet al., 2002).

$\mathrm{N}$ is the form of urea was applied during planting $(50 \%)$, and at two $(25 \%)$ and three (25\%) months after planting. The application of $200 \mathrm{~kg} \mathrm{~N} / \mathrm{ha}$ resulted in the greatest number of leaves per plant (23.15) and plant height $(19.90 \mathrm{~cm}) . \mathrm{N}$ at $150 \mathrm{~kg} / \mathrm{ha}$ gave the highest number of flowers per plant(3.95), fruit set $(68.35 \%)$, fruit length $(2.56 \mathrm{~cm})$ and width $(2.04 \mathrm{~cm})$, number of fruits per plant(16.7), average fruit weight $(7.90 \mathrm{~g})$, and total fruit yield per plant (137.75 g) (Gaur and Gangwar, 2003).

The maximum plant height $(24.51 \mathrm{~cm})$, number of leaves (26.20), leaf area (92.66 $\mathrm{cm} 2)$, fruit length $(35.80 \mathrm{~mm})$, fruit breadth $(23.24 \mathrm{~mm})$, fruit weight $(9.17 \mathrm{~g})$, TSS $(8.60$ 
degrees Brix) and total sugars (7.58\%) were recorded with $100 \mathrm{~kg} \mathrm{~N} / \mathrm{ha}$. However, the maximum yield $(74.81 \mathrm{q} / \mathrm{ha})$ and number of runners per plant (18.69) were obtained with $80 \mathrm{~kg} \mathrm{~N} / \mathrm{ha}$ (Rana and Chandel, 2003).

\section{Materials and Methods}

The present investigation at the Crop Research Farm, Department of Horticulture, SHIATS, Allahabad, (U.P.) India. Location and experimental site is situated at of a latitude of $20^{\circ}$ and $15^{\circ}$ North and longitude of $60^{\circ} 3$ " East and at an altitude of 98 meters above mean sea level (MSL). The maximum temperature of the location reaches up to $46^{\circ} \mathrm{C}$ $-48^{\circ} \mathrm{C}$ and seldom falls as low as $4^{\circ} \mathrm{C}-5^{\circ} \mathrm{C}$. The relative humidity $20-94$ percent. The average rainfall in this area is around $1013.4 \mathrm{~mm}$ annually. The soil is experimental area had sand $60 \%$, Silt $26 \%$, Clay $14 \%, \mathrm{pH}$ 7.2, Soil EC. $\left(\mathrm{dSm}^{-1}\right)$ at $25^{\circ}$ C. 0.28 , Organic carbon $0.35 \%$, and soil containing available (Nitrogen 240.33, phosphorus, potassium $\mathrm{Kg} /$ ha.) application of FYM 15 tones $\mathrm{ha}^{-1}$.

The experiment was laid out in randomized block design, comprising of 9 treatment combinations each replicated thrice. Treatments were randomly arranged in each replication, divided into 27 plots. The treatments combinated specifications of the layout, etc. are given below. $\mathrm{T}_{0}-$ control, $\mathrm{T}_{1}-$ RDF $50 \%$ + Azotobacter $6 \mathrm{~kg} / \mathrm{ha}^{-1}, \mathrm{~T}_{2}-\mathrm{RDF}$ $75 \%+$ Azotobacter $6 \mathrm{~kg} / \mathrm{ha}^{-1}, \mathrm{~T}_{3}-\mathrm{RDF} 100 \%$ + Azotobacter $6 \mathrm{~kg} / \mathrm{ha}^{-1}, \mathrm{~T}_{4}-\mathrm{RDF} 50 \%+\mathrm{PSB}$ $5 \mathrm{~kg} / \mathrm{ha}^{-1}, \mathrm{~T}_{5}-\mathrm{RDF} 75 \%+\mathrm{PSB} 5 \mathrm{~kg} / \mathrm{ha}^{-1}, \mathrm{~T}_{6}-$ RDF $100 \%+$ PSB $5 \mathrm{~kg} / \mathrm{ha}^{-1}, \mathrm{~T}_{7}$ RDF $50 \%+$ Azotobacter $6 \mathrm{~kg} / \mathrm{ha}^{-1}+\mathrm{PSB} 5 \mathrm{~kg} / \mathrm{ha}^{-1}, \mathrm{~T}_{8^{-}}$ $\mathrm{RDF} 75 \%+$ Azotobacter $6 \mathrm{~kg} / \mathrm{ha}^{-1}+$ PSB 5 $\mathrm{kg} / \mathrm{ha}^{-1}, \mathrm{~T}_{9} \mathrm{RDF} 100 \%+$ Azotobacter $6 \mathrm{~kg} / \mathrm{ha}$ ${ }^{1}+$ PSB $5 \mathrm{~kg} / \mathrm{ha}^{-1}$.

Fertilizer Dose- 150:75:10020 tones FYM ha ${ }^{1}$ was applied before 15 days of planting. The half dose of Nitrogen $\left(75 \mathrm{~kg} \mathrm{ha}^{-1}\right)$ and full dose of Phosphorous (75 kg ha $\left.{ }^{-1}\right), \mathrm{K}_{2} \mathrm{O}$ (100 $\mathrm{kg} \mathrm{ha}^{-1}$ ) were applied in basal dose to each pot. The remaining half dose of Nitrogen was applied in two split doses by applying half of it after the establishment of plants in 40 days and remaining half dose 60 days. The chemical fertilizers used to supply N, P and K were urea, Single Super Phosphate and Muriate of Potash respectively. The seedlings were inoculated with Azotobacter and PSB by root dipping for five minutes in the respective microbial suspensions. Azotobacter and PSB was also applied by placing the five centimeters below the surface of the soil in each plot before transplanting.

\section{Results and Discussion}

The maximum fruit weight (g / fruit) was recorded in $\mathrm{T}_{9}$ : RDF $100 \%$ (150:75:100 kg $\left.\mathrm{ha}^{-1}\right)+$ Azotobacter $6 \mathrm{~kg} \mathrm{ha}^{-1}+$ PSB $5 \mathrm{~kg} \mathrm{ha}^{-1}$ with $(23.18 \mathrm{~g})$, followed by $\mathrm{T}_{8}$ : RDF $75 \%$ (150: $75: 100 \mathrm{~kg} \mathrm{ha}^{-1}$ ) Azotobacter $6 \mathrm{~kg} \mathrm{ha}^{-1}$ + PSB $5 \mathrm{~kg} \mathrm{ha}^{-1}$ with (20.23 g) and the minimum was recorded in $\mathrm{T}_{0}$ (control)) with $(10.87 \mathrm{~g})$. The maximum fruit index (Ratio of fruit length and fruit diameter) was recorded in $\mathrm{T}_{9}$ : RDF 100\% (150: $\left.75: 100 \mathrm{~kg} \mathrm{ha}^{-1}\right)+$ Azotobacter $6 \mathrm{~kg} \mathrm{ha}^{-1}+$ PSB $5 \mathrm{~kg} \mathrm{ha}^{-1}$ with (1.56), followed by $\mathrm{T}_{8}$ : RDF $75 \%$ (150: 75 : $100 \mathrm{~kg} \mathrm{ha}^{-1}$ ) Azotobacter $6 \mathrm{~kg} \mathrm{ha}^{-1}+$ PSB $5 \mathrm{~kg}$ $\mathrm{ha}^{-1}$ with (1.50) and the minimum was recorded in $\mathrm{T}_{0}$ (control)) with (1.28). Similar findings have also been reported by Shashi et $a l .$, (2008) in strawberry.

The maximum specific gravity of fruits was recorded in $\mathrm{T}_{9}$ : RDF $100 \%$ (150: $75: 100 \mathrm{~kg}$ $\left.\mathrm{ha}^{-1}\right)+$ Azotobacter $6 \mathrm{~kg} \mathrm{ha}^{-1}+$ PSB $5 \mathrm{~kg} \mathrm{ha}^{-1}$ with (2.19), followed by $\mathrm{T}_{8}$ : RDF $75 \%$ (150 : 75 : $100 \mathrm{~kg} \mathrm{ha}^{-1}$ ) Azotobacter $6 \mathrm{~kg} \mathrm{ha}^{-1}+$ PSB $5 \mathrm{~kg} \mathrm{ha}^{-1}$ with (2.01) and the minimum was recorded in $\mathrm{T}_{0}$ (control) with (1.62). Similar finding have also been reported by Shashi et al., (2008) in Strawberry. 
Table.1 Effect of Effect of Bio fertilizers with different levels of N, P and K on K on physico-chemical properties of strawberry

\begin{tabular}{|c|c|c|c|c|c|c|c|c|}
\hline Treatment & $\begin{array}{c}\text { Weight of } \\
\text { fruit (g) }\end{array}$ & $\begin{array}{l}\text { Fruits } \\
\text { index }\end{array}$ & $\begin{array}{c}\text { Specific gravity } \\
\text { of fruits }\end{array}$ & $\begin{array}{c}\text { T.S.S (\%) } \\
\text { of fruits }\end{array}$ & $\begin{array}{l}\text { pH of } \\
\text { fruits }\end{array}$ & $\begin{array}{l}\text { Acidity }(\%) \text { of } \\
\text { fruits juice }\end{array}$ & $\begin{array}{c}\text { Vitamin-C of fruits } \\
(\mathrm{mg} / \mathrm{100g})\end{array}$ & $\begin{array}{l}\text { Juice content }(\%) \text { of } \\
\text { fruits }\end{array}$ \\
\hline $\mathbf{T}_{\mathbf{0}}$ & 10.87 & 1.28 & 1.62 & 8.38 & 2.59 & 0.71 & 47.13 & 80.42 \\
\hline $\mathbf{T}_{1}$ & 15.97 & 1.48 & 1.81 & 9.61 & 2.72 & 0.68 & 48.53 & 83.07 \\
\hline $\mathbf{T}_{2}$ & 17.41 & 1.46 & 1.86 & 9.41 & 2.77 & 0.67 & 49.07 & 82.84 \\
\hline $\mathbf{T}_{\mathbf{3}}$ & 15.93 & 1.48 & 1.79 & 9.79 & 2.84 & 0.65 & 49.53 & 84.48 \\
\hline $\mathbf{T}_{4}$ & 15.72 & 1.40 & 1.91 & 9.45 & 2.67 & 0.66 & 48.67 & 81.96 \\
\hline $\mathbf{T}_{5}$ & 17.21 & 1.42 & 1.90 & 9.55 & 2.81 & 0.63 & 49.27 & 82.78 \\
\hline $\mathbf{T}_{6}$ & 19.04 & 1.46 & 1.92 & 9.70 & 2.84 & 0.65 & 49.87 & 83.54 \\
\hline $\mathbf{T}_{7}$ & 17.09 & 1.42 & 1.89 & 9.51 & 2.77 & 0.69 & 48.73 & 83.06 \\
\hline $\mathbf{T}_{8}$ & 20.23 & 1.50 & 2.01 & 9.97 & 2.95 & 0.68 & 49.40 & 84.82 \\
\hline $\mathbf{T}_{9}$ & 23.18 & 1.56 & 2.19 & 10.09 & 3.08 & 0.56 & 50.13 & 85.61 \\
\hline $\begin{array}{c}\text { C D. } \\
(0.5 \%)\end{array}$ & 3.10 & 0.08 & 0.28 & 0.51 & 0.13 & 0.02 & 0.65 & 2.52 \\
\hline
\end{tabular}


The maximum total soluble solid (T.S.S. ${ }^{0}$ Brix) of fruits was recorded in $T_{9}$ : RDF $100 \%\left(150: 75: 100 \mathrm{~kg} \mathrm{ha}^{-1}\right)+$ Azotobacter 6 $\mathrm{kg} \mathrm{ha}^{-1}+$ PSB $5 \mathrm{~kg} \mathrm{ha}^{-1}$ with (10.09), followed by $\mathrm{T}_{8}$ : RDF $75 \%$ (150: $\left.75: 100 \mathrm{~kg} \mathrm{ha}^{-1}\right)$ Azotobacter $6 \mathrm{~kg} \mathrm{ha}^{-1}+$ PSB $5 \mathrm{~kg} \mathrm{ha}^{-1}$ with (9.97) and the minimum was recorded in $\mathrm{T}_{0}$ (control) with (8.38). The minimum T.S.S. content $(8.38 \%)$ was recorded in $\mathrm{T}_{0}$ (control). However, there was a significant difference among all the treatments. The decline in T.S.S. might be due to the fact that increased nitrogen has showed excessive growth consumed most of the metabolites. These results coincide with the respect El-Hamd et al., (2006), Sahoo and Singh (2005), Shashi et al., (2008) and Umar et al., (2010)

The maximum $\mathrm{pH}$ of fruit juice was recorded in $\mathrm{T}_{9}: \mathrm{RDF} 100 \%\left(150: 75: 100 \mathrm{~kg} \mathrm{ha}^{-1}\right)+$ Azotobacter $6 \mathrm{~kg} \mathrm{ha}^{-1}+$ PSB $5 \mathrm{~kg} \mathrm{ha}^{-1}$ with (3.08), followed by $\mathrm{T}_{8}$ : RDF $75 \%$ (150: 75 : $100 \mathrm{~kg} \mathrm{ha}^{-1}$ ) Azotobacter $6 \mathrm{~kg} \mathrm{ha}^{-1}+$ PSB $5 \mathrm{~kg}$ $\mathrm{ha}^{-1}$ with (2.95) and the minimum was recorded in $\mathrm{T}_{0}$ (control) with (2.59). The results are supported by Gogoi et al., (2004) in Strawberry.

The minimum acidity (\%) of fruit juice was recorded in $\mathrm{T}_{9}: \mathrm{RDF} 100 \%(150: 75: 100 \mathrm{~kg}$ $\left.\mathrm{ha}^{-1}\right)+$ Azotobacter $6 \mathrm{~kg} \mathrm{ha}^{-1}+$ PSB $5 \mathrm{~kg} \mathrm{ha}^{-1}$ with $(0.56)$, followed by $\mathrm{T}_{5}:$ RDF $75 \%$ (150 : $\left.75: 100 \mathrm{~kg} \mathrm{ha}^{-1}\right)+$ PSB $5 \mathrm{~kg} \mathrm{ha}^{-1}$ with $(0.63)$ and the maximum was recorded in $T_{0}$ (control) with (0.71). The results are supported by Gogoiet al., in Strawberry. (2004).

The maximum Vitamin $-\mathrm{C}$ content of fruits (mg / 100g) was recorded in $\mathrm{T}_{9:}$ RDF $100 \%$ $\left(150: 75: 100 \mathrm{~kg} \mathrm{ha}^{-1}\right)+$ Azotobacter $6 \mathrm{~kg}$ $\mathrm{ha}^{-1}+$ PSB $5 \mathrm{~kg} \mathrm{ha}^{-1}$ with (50.13) and the minimum was recorded in $\mathrm{T}_{0}$ : control with (47.13). El-Hamd et al., (2006) and Sahoo and Singh (2005) in Strawberry.
The maximum juice content (\%) of fruits was recorded in $\mathrm{T}_{9}: \mathrm{RDF} 100 \%$ (150: $75: 100 \mathrm{~kg}$ $\left.\mathrm{ha}^{-1}\right)+$ Azotobacter $6 \mathrm{~kg} \mathrm{ha}^{-1}+$ PSB $5 \mathrm{~kg} \mathrm{ha}^{-1}$ with $(85,61 \%)$, followed by $\mathrm{T}_{8}$ : RDF $75 \%$ (150: $75: 100 \mathrm{~kg} \mathrm{ha}^{-1}$ ) Azotobacter $6 \mathrm{~kg} \mathrm{ha}^{-1}$ + PSB $5 \mathrm{~kg} \mathrm{ha}^{-1}$ with $(84.82 \%)$ and the minimum was recorded in $\mathrm{T}_{0}$ (control) with $(80.42 \%)$. It was interesting to note that a positive relationship exist between specific gravity of fruits and juice content. Similar results have been reported by Shashi et al., (2008).

The present investigation at the Crop Research Farm, Department of Horticulture, SHIATS, Allahabad, (U.P.) India was concluded that physic-chemical properties of strawberry like the maximum fruit weight ( $\mathrm{g} /$ fruit), maximum fruit index (Ratio of fruit length and fruit diameter), the maximum specific gravity of fruits, the maximum total soluble solid (T.S.S. ${ }^{0}$ Brix) of fruits, the maximum $\mathrm{pH}$ of fruit juice, the minimum acidity (\%) of fruit juice, the maximum Vitamin $-\mathrm{C}$ content of fruits $(\mathrm{mg} / 100 \mathrm{~g})$ and the maximum juice content $(\%)$ of fruits was recorded in $\mathrm{T}_{9}$ : RDF $100 \%$ (150: $75: 100 \mathrm{~kg}$ $\left.\mathrm{ha}^{-1}\right)+$ Azotobacter $6 \mathrm{~kg} \mathrm{ha}^{-1}+$ PSB $5 \mathrm{~kg} \mathrm{ha}^{-1}$ with (23.18 g).

\section{References}

Anonymous (2014). French, Ministry of Agriculture and the Statistical Division(FAOSTAT,January,2013)

(FAOSTAT). The Food and Agriculture Organization of the United Nations (FAO).

Baba, Z.A., Zargar M.Y. and Mir S.A. (2010). Effect of inorganic and biofertilizers on soil physicochemical properties and micronutrient availibility in strawberry (Fragaria $\times$ ananassa Duch).An Asian J. Soil Sci., 5(1): 90-93.

El-Hamd, A.S.A.A.; Abdou, A.A.; Mansouor, S.A.A. and El-Sayed, A.A.A. (2006). 
Effect of some biofertilizer on the yield and the fruit quality of strawberry. Ann. Agri. Sci. Moshtohor, 44 (1): 251-264.

Forney, C. F. and Breen, P. J. (1986). sugar content and uptake in the strawberry fruit. J. of the American society for hort. Sci., 111 (2): 241-47.

Gaur, G. S. and Gangwar Deepak (2003). Effects of different levels of nitrogen on the growth, yield and quality of strawberry (Fragaria $x$ ananassaDuch.) cv.Seascape. Prog. Agri.,3 (1/2) 150151.

Gogoi, D; Kotoky, V. and Hazarika, S. (2004).Effect of biofertilizer on productivity and soil characteristics in banana. Indian J. Hort., 61 (4): 354356.

Mitra, S.K. (1991). Strawberries. (in): Temperate Fruit. (Bose, T.K., Mitra, S.K. and Rathore, D.S. Eds.). Horticulture and Allied publishers, Calcutta, Pp. 549-596.

Rana, R. K. and Chandel, J. S. (2003). Effect of biofertilizers and nitrogen on growth, yield and fruit quality of strawberry. Prog. Hort., 35 (1): 25-30.

Roberts, A. N. and Kenworthy, A. L. (1956). Growth and composition of strawberry plant in relation to root temperature and intensity of nutrition. Proceedings of the American society for Hort. Sci., 58: 157-60.

Sahoo, S. K. and Singh, D. B. (2005). Effect of different levels of biofertilizers on growth, yield and quality of strawberry (Fragaria X ananassa Duch) cv. Sweet Charley. Orissa J. Hort., 33 (2): 82-85.

Sharma, R.M. and Yamdagni (2000). Modern strawberry cultivation Kalyani Publications B - 1/1292. Rajender Nagar, Ludhiana, P. 1-2

Shashi Kamal, Virenderkumar, Sanjay Rana, and Singh, M.P. (2008). Response of inoculation of biofertilizers on flowering, quality and yield of tomato (Lycopersiconesculentum Mill.). Envt. And Eco., 26 (4) 1858-1861.

Shiow, Y.W. and Shin, S.L. (2002). Composts as soil supplement enhanced plant grouth and fruit quality of strawberry. $J$. of plants nutritio., 25(10): 2243-2259.

Umar, I.; Wali, V. K.; Rehman, M. U.; Mir, M. M.; Banday, S. A. and Bisati, I. A. (2010).Effect of subabul urea and biofertilizer application on growth, yield and quality of strawberry cv. Chandler. Applied Biological Res., 12 (2): 50-54.

\section{How to cite this article:}

Naiem Ansari, Sevan Das Khunte and Prasad, V.M. 2020. Effect of Bio fertilizers with Different Levels of N, P and K on physico-chemical Properties of Strawberry (Fragaria $x$ ananassa Duch.) cv. Chandler. Int.J.Curr.Microbiol.App.Sci. 9(01): 727-732.

doi: https://doi.org/10.20546/ijcmas.2020.901.079 